\title{
Effect of alpha methyl dopa on experimental tremor
}

\author{
H. SCHNIEDEN
}

\author{
From the Institute of Neurology, Queen Square, London
}

The majority of the drugs employed in the treatment of Parkinsonism are anticholinergic compounds. Thus benzhexol (Artane), benztropine (Cogentin), and orphenadrine (Disipal) all belong to this group. Ahmed and Marshall (1962) have suggested that there is a relationship between the anticholinergic potency of a drug on the one hand and its value in Parkinsonism on the other. This would accord with the view of Feldberg (1945) that atropine is effective in Parkinsonism because it antagonizes the action of acetylcholine at central synapses and that of Jenkner and Ward (1953) that hypersensitivity to acetylcholine occurs in the region of an experimental tremor-producing lesion.

Experimental tremor is also modified by 5 hydroxytryptamine and by adrenergic compounds. Domer and Feldberg (1960) showed that 5-hydroxytryptamine will produce a tremor in cats if injected intraventricularly, and Carmichael, Feldberg, and Fleischhauer (1962) have observed that intraventricular injection of dopamine, noradrenaline, or adrenaline modifies the tremor produced by intraventricular d-tubocurarine in the cat. In man, on the other hand, intravenous adrenaline aggravates Parkinsonian tremor (Barcroft, Peterson, and Schwab, 1952; Constas, 1962).

The introduction of $\alpha$ methyl dopa for the treatment of hypertension has presented an opportunity for the further study of the pharmacology of tremor. $\alpha$ Methyl dopa inhibits the formation of both dopamine and 5-hydroxytryptamine in the brains of experimental animals (Sourkes, 1961), hence it might be expected to affect tremor. Moreover, dopamine occurs in large concentrations in the basal ganglia (Carlsson, 1959) which are the structures affected in Parkinsonism. In this paper the effect of $\alpha$ methyl dopa on the tremor produced in mice by several pharmacological agents is noted, and in the subsequent paper the results of a double-blind trial in patients with Parkinsonism will be reported (Marsh, Schnieden, and Marshall, 1963).

\section{METHODS}

Tremor was measured in male mice (weight 20 to $40 \mathrm{~g}$.) by modification of the method of Ahmed and Taylor (1959).

The mouse was placed in a small box connected by a stylus to a gramophone pick-up. Movement of the mouse activated the pick-up, the output of which after amplification could drive an Ediswan pen recorder. Alternatively, after passage through a transistorized circuit containing a frequency selective amplifier, a digital counter was activated. Hence, either a graphic record of, or a numerical value for, the degree of tremor could be obtained; the latter made handling of the data easier. The use of the frequency selective amplifier decreased the error produced by voluntary movement of the animal, as the latter produced waves of lower amplitude than did the tremor. Full details of the circuit are given in the appendix.

The sedative effect of $\alpha$ methyl dopa was tested using the method of Dews (1953). In this method five treated animals are placed in a large darkened box and five controls in a similar box. Shining from one side to the? other, across the centre of the box, is a thin beam of light which impinges onto a photoelectric cell which in turn is, by suitable means, connected to a digital counter. A mouse crossing the beam activates the circuit so that numerical figures related to the total movement of the five treated mice or their controls are obtained. Mices were observed at various intervals after the intra? peritoneal injection of $\alpha$ methyl dopa $(35 \mathrm{mg} . / \mathrm{kg}$. of $200 \mathrm{mg} . / \mathrm{kg}$.), the period of time they were left in the darkened boxes being five minutes on each occasion. All experiments were carried out in a room, the temperature of which was kept at $25 \pm 1^{\circ} \mathrm{C}$.

Tremor was induced by the intraperitoneal injection of the following drugs: Tremorine dihydrochloride $40 \mathrm{mg}$./ $\mathrm{kg}$., nicotine hydrogen tartrate $15 \mathrm{mg} . / \mathrm{kg}$., harmine $30 \mathrm{mg}$. $/ \mathrm{kg}$., 5 hydroxytryptophan $200 \mathrm{mg}$. $/ \mathrm{kg}$., and methyl amphetamine $20 \mathrm{mg} . / \mathrm{kg}$. Laevo $\alpha$ methyl dopa, 200 $\mathrm{mg} . / \mathrm{kg}$. or $35 \mathrm{mg}$. $/ \mathrm{kg}$., was given intraperitoneally but atropine, $1.5 \mathrm{mg} . / \mathrm{kg}$., was given subcutaneously. All animals were allowed food and water freely up to one hour before the measurement of tremor.

\section{RESULTS}

Figure 1 shows that when an untreated mouse was placed in its box the pick-up was activated due to the mouse indulging in exploratory activity or cleaning movements. When left undisturbed, the mouse quickly settled down and, as can be seen from the tracing after 40 minutes spontaneous activity had virtually disappeared. For this reason, all animals were given an initial period of $\mathbf{4 0}$ minutes in which to settle down. When the mouse was injected with tremorine, the pick-up was markedly activated due 


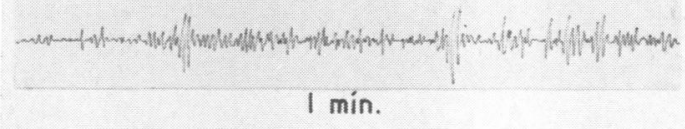

$15 \mathrm{~min}$.

$25 \mathrm{~min}$

$40 \mathrm{~min}$.

FIG. 1
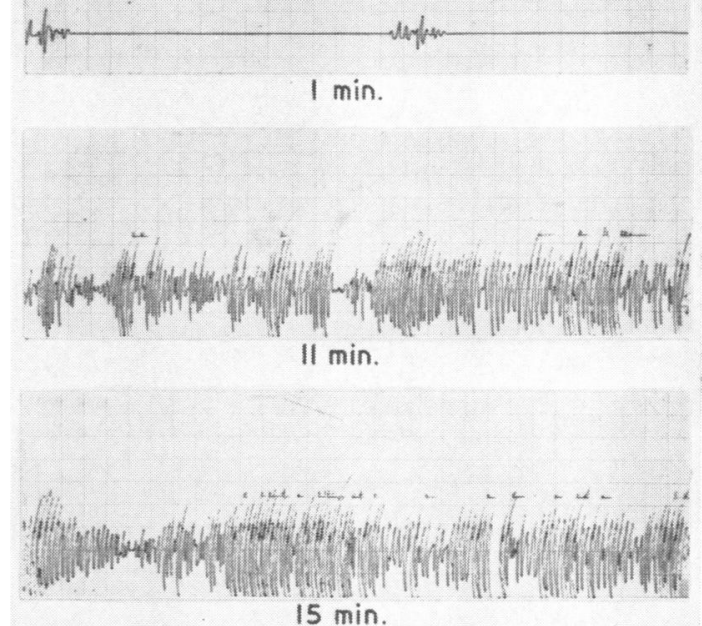

$15 \mathrm{~min}$

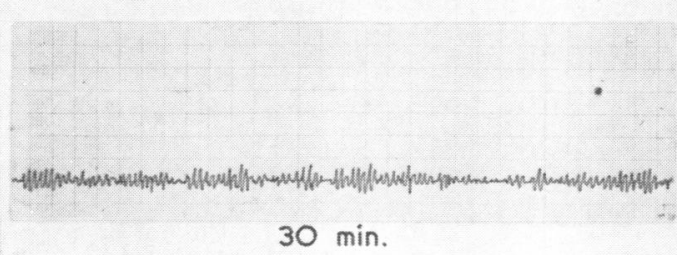

FIG. 2

$\mathrm{v}^{\wedge} 40 \mathrm{~mm}$.

to the severe tremor produced (Fig. 2). In practice, tremorine tremor was recorded between the tenth and eleventh minute after the administration of tremorine.

EFFECT OF DRUGS ON TREMORINE-INDUCED TREMOR Atropine is known to inhibit tremorine-induced tremor (Blockus and Everett, 1957), and this fact was used to check the sensitivity of the modified method. Figure 3 shows that pretreatment with atropine 40 minutes before the administration of tremorine reduced the degree of tremor by approximately $80 \%$. Figure 4 shows the effect of pretreatment with $\alpha$ methyl dopa $(200 \mathrm{mg}$. $/ \mathrm{kg}$.) on tremorineinduced tremor. As can be seen, pretreatment from a quarter of an hour up to six hours previously had no effect on tremorine-induced tremor.

EFFECT OF $\alpha$ METHYL DOPA ON TREMOR INDUCED
BY NICOTINE, HARMINE, METHYL AMPHETAMINE, AND 5 HYDROXYTRYPTOPHAN $\propto$ Methyl dopa failed to inhibit nicotine-induced tremor when given one and a half to six hours previously and methyl amphetamine tremor when given two hours previously. When $\alpha$ methyl dopa was administered 157 minutes before harmine there was a barely significant reduction of the tremor induced by this drug (Table I). However, pretreatment with $\alpha$ methyl dopa given 97 and 217 minutes before the injection of harmine failed to decrease the tremor response.

In contrast to the three previously mentioned druginduced tremors $\alpha$ methyl dopa reduced significantly the tremor produced by 5 hydroxytryptophan (Fig. 5).

EFFECT OF $\alpha$ METHYL DOPA ON ACTIVITY Figure 6 shows that $\alpha$ methyl dopa has a sedative action which was more marked and longer acting when $200 \mathrm{mg} . / \mathrm{kg}$. was administered than when $35 \mathrm{mg} . / \mathrm{kg}$. was given. 
TABLE I

EFFECT OF $\alpha$ METHYL DOPA ON PHARMACOLOGICALLY INDUCED TREMOR IN MICE

\begin{tabular}{|c|c|c|c|}
\hline $\begin{array}{l}\text { Time of Administration (min.) } \\
\text { of } \alpha \text { Methyl Dopa before } \\
\text { Tremor Recording }{ }^{2}\end{array}$ & $\begin{array}{l}\text { Tremor-producing Agent and Dose } \\
(\mathrm{mg} . / \mathrm{kg} . \text { body wt.) }\end{array}$ & $\begin{array}{l}\text { Tremor Recorded after } \\
\text { Injection of Tremor-inducing } \\
\text { Agent (min.) }\end{array}$ & $\begin{array}{l}\text { Effect of a Methyl } \\
\text { Dopa in Modifying } \\
\text { Tremor }\end{array}$ \\
\hline $\begin{array}{l}90(8)^{1}, 180(8), 300(8) \\
127(10) \\
140(12) \\
160(8) \\
100(8), 220(8)\end{array}$ & $\begin{array}{l}\text { Nicotine hydrogen tartrate, } 15 \\
\text { Methyl amphetamine, } 20 \\
5 \text { hydroxytryptophan, } 200 \\
\text { Harmine, } 30 \\
\text { Harmine, } 30\end{array}$ & $\begin{array}{l}1-3 \\
7-10 \\
60-61 \\
3-5 \\
3-5\end{array}$ & $\begin{array}{l}\text { None } \\
\text { None } \\
\text { Inhibited }(P<0.02) \\
\text { Inhibited }(P<0.05) \\
\text { None }\end{array}$ \\
\hline
\end{tabular}

${ }^{1}$ Figures in parenthesis are number of animals used.

${ }^{2}$ The pretreatment dose of $a$ methyl dopa was $200 \mathrm{mg} . / \mathrm{kg}$. intraperitoneally.

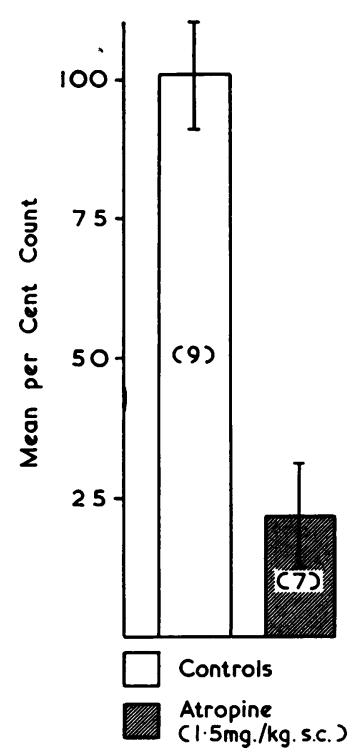

FIG. 3
FIG. 3. Effect of atropine on tremorine-induced tremor (mean \pm S.E.). Readings taken between tenth and eleventh minute after tremorine, $40 \mathrm{mg} . / \mathrm{kg}$., injected intraperitoneally. The effect in the mice given atropine expressed as a percentage of that obtained in the controls. Figures in parenthesis are number of animals used.

FIG. 4. Effect of pretreatment with $200 \mathrm{mg} . / \mathrm{kg}$. a methyl dopa on tremorine-induced tremor. Readings taken between tenth and eleventh minute after tremorine injected. Results obtained expressed as percentage of that obtained in controls. Figures beneath standard error are number of animals in the group.

FIG. 5. Effect of $\alpha$ methyl dopa on 5 hydroxytryptophaninduced tremor. (For details of dosage of 5 hydroxytryptophan and time of pretreatment with $\alpha$ methyl dopa see Table I.) Figures in parenthesis are number of animals used. Results obtained expressed as percentage of that obtained in controls.

FIG. 6. Effect of a methyl dopa on activity of mice.

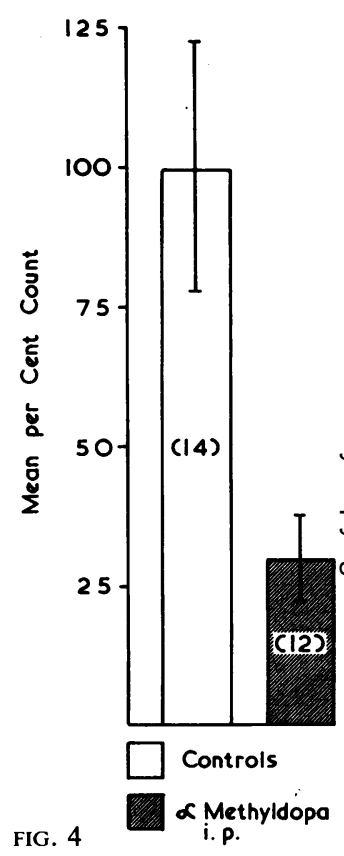

FIG. 4

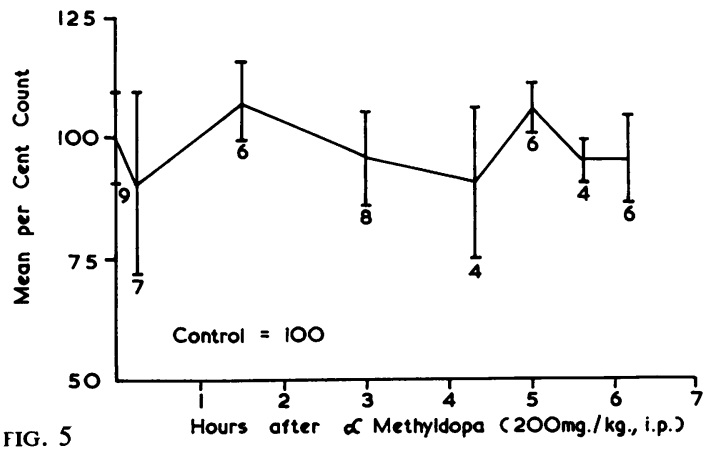

FIG. 5

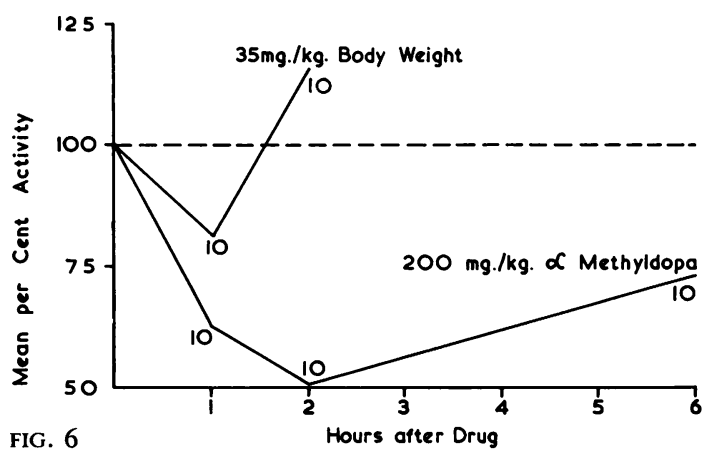




\section{DISCUSSION}

Tremorine is known to have marked muscarinic effects (Everett, 1961) and anticholinergic drugs antagonize the tremor it produces (Blockus and Everett, 1957). The failure of $\alpha$ methyl dopa to antagonize tremorine-and nicotine-produced tremor strongly suggests, therefore, that the drug does not appreciably modify transmission through central cholinergic pathways.

The inhibition of 5 hydroxytryptophan-induced tremor could be explained on the basis of 5 hydroxytryptophan forming 5 hydroxytryptamine, the latter being the tremor-producing agent. Since $\alpha$ methyl dopa inhibits decarboxylases it will stop the decarboxylation of 5 hydroxytryptophan to 5 hydroxytryptamine (Westerman, Balzer, and Knell, 1958), and so could prevent tremor from appearing.

Harmine is a short-acting monoamine oxidase inhibitor and hence would tend to raise 5 hydroxytryptamine levels and, to a lesser extent, noradrenaline levels in the brain. This action would be opposed by pretreatment with $\alpha$ methyl dopa which would tend to decrease these levels (Smith, 1959; Hess, Connamacher, Ozaki, and Udenfriend, 1961). On these grounds, antagonism of harmine tremor might be expected. It is of interest that the maximum depleting effect of $\alpha$ methyl dopa on brain 5 hydroxytryptamine levels occurs at about three hours after intraperitoneal injection of the drug (Porter, Totaro, and Leiby, 1961), and it is at approximately this time that it produces its significant effect on harmine tremor.

An alternative possibility is suggested by the experiments of Hara and Kawamori (1954) and Zetler (1957) who have shown that harmine tremor can be antagonized by a number of drugs including sedatives. Since $\alpha$ methyl dopa has a sedative action this might be the basis of its antagonistic effect.

$\alpha$ Methyl dopa was unable to antagonize methyl amphetamine-induced tremor. The amphetamine group is also able to inhibit amine oxidase, but amphetamines possess other properties as well. Reinert (1960) showed that amphetamine and its derivatives had effects similar to nicotine on the superior cervical ganglion and suggested that the central action of these drugs might be by way of a nicotinic excitation and depression. Vane (1960) also suggested that the central effects of amphetamine are nothing to do with its sympathomimetic-like action. If methyl amphetamine produced tremor by a nicotinic action on the central nervous system then, since $\alpha$ methyl dopa was ineffective against nicotineinduced tremor, it might be expected to fail to diminish methyl amphetamine-induced tremor also.

The main effect of $\alpha$ methyl dopa appears, there- fore, to be on the 5-hydroxytryptamine tremorproducing pathway; it is ineffective against the muscarinic and nicotinic pathways.

Why $\alpha$ methyl dopa has a sedative action is not clear. One possibility is suggested by the work of Hess et al. (1961) who postulated that that $\alpha$ methyl dopa, in addition to producing decarboxylase inhibition, modifies the binding sites for noradrenaline and possibly for 5 hydroxytryptamine. Release of free 5 hydroxytryptamine could cause sedation. The work of Gillespie, Oates, Crout, and Sjoerdsma (1962) also suggests that $\alpha$ methyl dopa has other properties besides inhibition of decarboxylase since they noted that other potent decarboxylase inhibitors failed to reduce the blood pressure in hypertensive patients whereas $\alpha$ methyl dopa could do so.

Clearly $\alpha$ methyl dopa has potentialities as a tremor-inhibiting agent and deserves further study both experimentally and clinically.

\section{SUMMARY}

In mice, the tremor induced by methyl amphetamine, tremorine, or nicotine was not modified by pretreatment with $\alpha$ methyl dopa. However, the later drug did modify the tremor produced by harmine and 5 hydroxytryptophan.

In addition it could be shown that $\alpha$ methyl dopa has a sedative action when given at a dose level of $200 \mathrm{mg}$. $/ \mathrm{kg}$. but the sedative effect was markedly less when given at a dose level of $35 \mathrm{mg} . / \mathrm{kg}$.

This work was made possible by a grant from May and Baker Ltd. in support of the Neuropharmacological Laboratory. I also wish to thank Dr. R. Wein and Dr. D. Maxwell, of May and Baker Ltd., for the use of certain items of equipment and for their helpful interest throughout this study, and Mr. L. Jacobs for technical assistance

\section{REFERENCES}

Ahmed, A., and Marshall, P. B. (1962). Brit. J. Pharmacol., 18, 247. _ and Taylor, N. R. W. (1959). Ibid., 14, 350.

Barcroft, H., Peterson, E., and Schwab, R. S. (1952). Neurology (Minneap.), 2, 154.

Blockus, L. E., and Everett, G. M. (1957). Fed. Proc., 16, 283.

Carlsson, A. (1959). Pharmacol. Rev., 11, 490.

Carmichael, E. A., Feldberg, W., and Fleischhauer, K. (1962). J. Physiol. (Lond.), 162, 539.

Constas, C. (1962). J. Neurol. Neurosurg. Psychiat., 25, 116.

Dews, P. B. (1953). Brit. J. Pharmacol., 8, 46.

Domer, F. R., and Feldberg, W. (1960). Ibid., 15, 578.

Everett, G. M. (1961). Extrapyramidal System and Neuroleptics: p. 182. Editon Psychiatriques Case Postale 6128, Montreal, Canada.

Feldberg, W. (1945), Physiol. Rev., 25, 596.

Gillespie, L. Jr., Oates, J. A., Crout, J. R., and Sjoerdsma, A. (1962). Circulation, 25, 281.

Hara, S., and Kawamori, K. (1954). Jap. J. Pharmacol., 3, 149.

Hess, S. M., Connamacher, R. H., Ozaki, M., and Udenfriend, S. (1961). J. Pharm. exp. Ther., 134, 129.

Jenkner, F. L., and Ward, A. Jr. (1953). A.M.A. Arch. Neurol. Psychiat., 70, 489.

Marsh, D. O., Schnieden, H., and Marshall, J. (1963). J. Neurol. Neurosurg. Psychiat, 26, 505. 


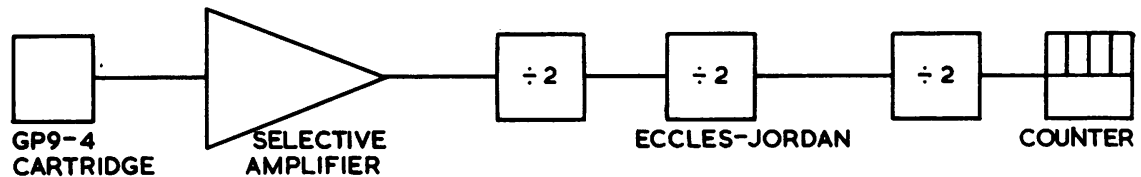

FIG. 7. Details of transistorized circuit used in the modified Ahmed and Taylor method for measuring tremor in small animals.
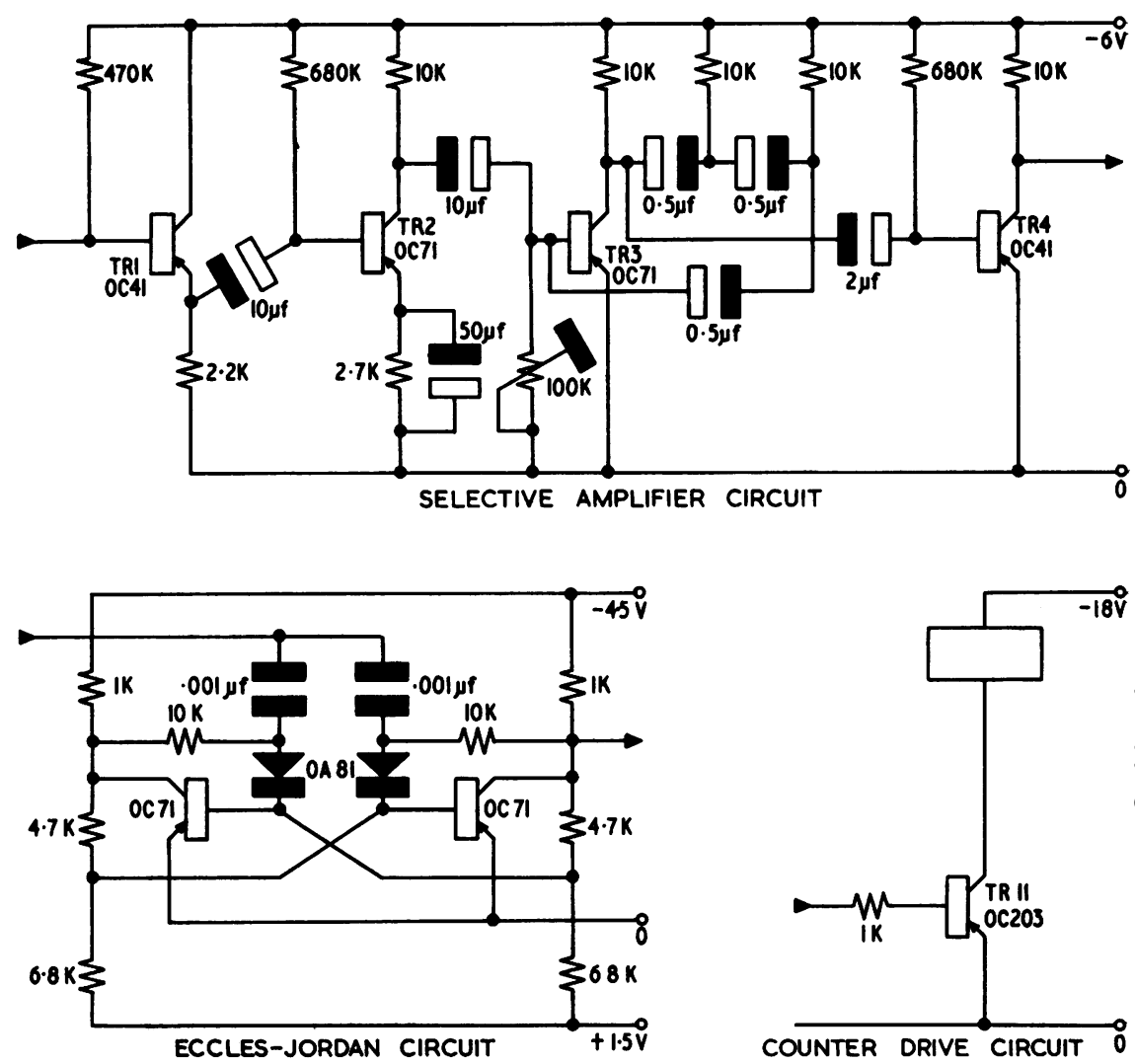

Mullard Reference Manual of Transistor Circuits. (1961). 2nd ed., p. 258. Wightman.

Porter, C. C., Totaro, J. A., and Leiby, C. M. (1961). J. Pharm. Exp. Ther., 134, 139.

Reinert, H. (1960). In Adrenergic Mechanisms, edited by J. R. Vane, G. E. W. Wolstenholme, and M. O'Connor, p. 373. Churchill, London.

Smith, S. E. (1959). J. Physiol. (Lond.), 148, 18P.

Sourkes, T. L. (1961). Extrapyramidal System and Neuroleptics, p. 91. International Symposium, Montreal. Editions Psychiatrique, Case Postale, 6128. Montreal, Canada.

Vane, J. R., (1960). In Adrenergic Mechanisms, edited by J. R. Vane, G. E. W. Wolstenholme, and M. O'Connor, p. 582. Churchill, London.

Westermann, E., Balzer, H., and Knell, J. (1958). Arch. exp. Path Pharmak., 234, 194.

Zetler, G. (1957). Ibid., 231, 34.

\section{APPENDIX}

J. D. GASKING From the Electronics Laboratory, May and Baker Ltd., Dagenham, Essex.
A soap dish containing a mouse was suspended from a gramophone pick-up cartridge mounted on a cantilever. Recording of tremor was made by amplifying the signal from the cartridge in a frequency selective amplifier tuned to $13 \mathrm{c} / \mathrm{s}$. The frequency of $13 \mathrm{c} / \mathrm{s}$. was found to be characteristic of the tremor and using a frequency selective amplifier reduced the effects of normal movements. The output of the amplifier was frequency divided by three Eccles Jordan circuits and made to drive an electromagnetic counter (Mullard, 1961).

The circuit used is shown in Figure 7. Signals from the cartridge are amplified and used to trigger the damped oscillator TR.3 tuned to the tremor frequency. The degree of damping is varied by the $100 \mathrm{~K}$ variable resistor in the base circuit TR.4. Limiting takes place in TR.4 giving a square wave to drive the three dividers. Output from the last divider drives the counter which is the collection load of TR.2. 